\title{
PERSPEKTIF ISLAM TERHADAP PENDIDIKAN KARAKTER (Islamic Perspectives On Character Education)
}

\author{
Felta Felta
}

\author{
Fakultas Sastra \\ Universitas Halu Oleo
}

\begin{abstract}
Abstrak
Karakter merupakan pilar utama dalam memajukan manusia tangguh, baik secara individu maupun kelompok. Dalam Islam, karakter lebih baik dikenal sebagai akhlaq Nabi ketika dia diutus sebagai utusan Allah di bumi. Didasarkan pada semangat pendidikan karakter saat ini, Makalah ini mengulas tentang bagaimana pendidikan karakter yang sebenarnya Islam. Padahal pendidikan karakter dalam Islam sedang terbentuk dalam istilah akhlakul karimah. Berdasarkan aspek metodologis. Metode pembiasaan dan keteladanan adalah cara terbaik untuk berkarakter pendidikan, yang membiasakan hal-hal baik hingga dianggap sebagai budaya dengan pikiran, perasaan dan tindakan. Dan Contoh hal yang baik kepada siswa sehingga nilai-nilai itu ditransfer ke dalam jiwa mereka, maka itu akan terjadi menghasilkan pengetahuan, serta terwujud dalam tindakan.
\end{abstract}

Kata kunci: Pendidikan, karakter, anak, perspektif, Islam 


\section{PENDAHULUAN}

\section{A. Latar Belakang}

Dalam rangka menghasilkan peserta didik yang unggul dan diharapkan, proses pendidikan senantiasa dievaluasi dan diperbaiki mengingat perkembangan zaman yang terus berkembang di era kecanggihan dan teknologi sekarang ini. Salah satu upaya perbaikan kualitas Pendidikan adalah munculnya gagasan mengenai Pendidikan karakter dalam dunia Pendidikan di Indonesia. Gagasan ini muncul karena proses yang dilakukan dinilai belum sepenuhnya berhasil dalam membangun manusia Indonesia yang berkarakter. Bahkan, ada juga yang menyebut bahwa Pendidikan Indonesia telah gagal dalam membangun karakter. Penilaian ini didasarkan pada banyaknya para lulusan sekolah dan sarjana yang cerdas secara intelektual, namun tidak bermental tangguh dan berperilaku tidak sesuai tujuan mulia Pendidikan.

Dunia intersubjektif ikut andil dalam menentukan kehidupan anak-anak remaja dalam lingkungan masyarakat. Artinya, tabiat, sifat, dan perilaku anak-anak remaja dipengaruhi oleh budaya dalam lingkungannya. Budaya tersebut termanifestasi dalam mengelola dan memengaruhi pembawaan sifat dan perilaku para remaja. Hal ini sejalan dengan pendapat Ritzer (dalam Susiati, et.al, 2021), dunia intersubjektif menciptakan suatu realitas sosial yang dipaksa oleh struktur budaya dan lingkungan sosial ciptaan leluhur mereka sebelumnya (hal. 35)

Oleh karena itu, pada diri remaja diperlukan sosialisasi dan internalisasi nilai-nilai semenjak mereka masih kecil. Ritzer (2014) mengatakan bahwa syarat dan fungsi bagi terpeliharanya integritas pola nilai di dalam sistem adalah proses internalisasi dan sosialisasi (hal. 86). Susiati (2019) mengatakan bahwa manusia adalah makhluk sosial yang perkembangan jiwanya tidak ditentukan sejak lahir tetapi dibentuk oleh lingkungannya. Lingkungan manusia itulah yang disebut kebudayaan (hal. 117).

Perilaku yang tidak sesuai dengan tujuan mulia Pendidikan misalnya tindak korupsi yang ternyata dilakukan oleh pejabat yang notabene adalah orang yang berpendidikan. Tindak korupsi ini termasuk penyalahgunaan jabatan dan wewenang. Belum lagi tindak kekerasan, padahal kita semua mengetahui dalam bermasyarakat kita harus saling menghargai dan menghormati bukan malah main hakim sendiri. Kemudian ditambah lagi dengan perilaku remaja Indonesia yang sama sekali tidak mencerminkan sebagai remaja yang terdidik. Misalnya, tawuran antar pelajar, tersangkut jaringan narkoba, atau melakukan tindak asusila yang berujung pada aborsi karena rasa malu akan hamil diluar nikah.

Kenyataan sebagaimana tersebut tentu saja membuat prihatin berbagai kalangan. Oleh karena itu, salah satu upaya perbaikan untuk Pendidikan di Indonesia adalah Pendidikan karakter. Upaya ini menjadi bagian dari proses pembentukan akhlak anak bangsa juga diharapkan mampu menjadi fondasi utama dalam mensukseskan Indonesia di masa mendatang.

Pendidikan merupakan pilar penting dalam perkembangan kognisi anak. Sejak dimulainya peradaban manusia disitu pulalah pendidikan muncul. Pendidikan adalah suatu runtunan dalam cara pemerolehan ilmu dan penyempurnaan diri yang dilakukan manusia secara terus menerus atau berkelanjutan. Manusia tidak luput dari keterbatasan 
dan kekurangan sehingga untuk melengkapi keterbatasan dan kekurangan yang dimiliki tersebut, manusia harus berproses, salah satunya melalui pemerolehan ilmu melalui pendidikan. Pendidikan yang diperoleh oleh manusia tidak hanya melalui pendidikan formal tetapi pendidikan awal yang didapatkan oleh manusia adalah melalui lingkungan keluarga dan lingkungan masyarakat (Tuasalamony et.al, 2020).

Peranan orang tua dalam membentuk suatu karakter anak sangatlah penting sebab pertama kali anak menerima sosialisasi dari lembaga keluarga. orang tua merupakan cerminan dari anak sehingga anak akan menjadi apa nantinya bergantung dari cara didikan orang tua terutama karakter khususnya dalam sikap religiusitas anak dalam bermasyarakat. Pendidikan beragama juga sangat penting diberikan kepada anak karena hal tersebut dapat menjadi bekal seorang anak dalam kehidupan bermasyarakat kelak. Peran orang tua dalam memberikan pendidikan religiusitas kepada anak sangat terlihat. Pendidikan religiusitas sangat penting bagi mereka untuk didapatkan oleh anak pada usia dini. Bagi para orang tua, dengan pendidikan agama yang diberikan kepada anak, dapat memberikan pemahaman tentang baik buruk dalam masyarakat sehingga anakanak tersebut kelak tidak terjerumus dalam hal-hal yang bersifat negatif (Buton, et.al, 2020).

Masyarakat menjadi lebih berfikir ilmiah terhadap segala tindakan khususnya dalam bidang pendidikan dan pengajaran terhadap para generasi atau para remaja. Dahulu masyarakat tidak mengutamakan pendidikan karena masyarakat menganggap bahwa berpendidikan tinggi sangat menguras harta. Selain itu, dulu banyak para remaja yang tidak melanjutkan sekolah di perguruan tinggi karena belum adanya Universitas di Kabupaten Buru. Padahal dengan mengenyam pendidikan sampai ke perguruan tinggi, jika selesai akan mengubah aspek kehidupan baik kepada diri sendiri maupun ketika berada di masyarakat (Hatuwe et.al, 2021).

\section{B. Rumusan Masalah}

Berdasarkan pemaparan latar belakang diatas, maka dapat dibuat rumusan masalah sebagai berikut:

1. Bagaimana pengertian pndidikan karakter?

2. Bagaimana urgensi pendidikan karakter?

3. Bagaimana pendidikaan karakter dalam perspektif Islam?

\section{Tujuan}

Makalah ini disusun guna memenuhi tugas isu-isu kontemporer dalam Pendidikan Islam. Diharapkan setelah membaca makalah ini kita dapat mengetahui:

1. Memahami pengertian pendidikan karakter

2. Memahami urgensi pendidikan karakter

3. Memahami Pendidikan karakter dalam perspektif Islam 


\section{PEMBAHASAN}

\section{A. Pengertian Pendidikan Karakter}

Pengertian karakter secara etimologis, kata karakter berasal dari bahasa Latin kharakter atau bahasa Yunani kharassein yang berarti memberi tanda (to mark), atau bahasa Prancis carakter, yang berarti membuat tajam atau membuat dalam.[1] Dalam bahasa Inggris character, memiliki arti: watak, karakter, sifat, dan peran. Dalam Kamus Besar Bahasa Indonesia, karakter diartikan sebagai tabiat, watak, sifat-sifat kejiwaan, akhlak, atau budi pekerti yang membedakan seseorang dari pada yang lain.

Secara terminologis, para ahli mendefinisikan karakter dengan redaksi yang berbeda-beda. Endang Sumantri menyatakan, karakter ialah suatu kualitas positif yang dimiliki seseorang sehingga membuatnya menarik dan atraktif; seseorang yang unusual atau memiliki kepribadian eksentrik." Doni Koesoema memahami karakter sama dengan kepribadian, yaitu ciri atau karakteristik, atau gaya, atau sifat khas dari diri seseorang yang bersumber dari bentukan-bentukan yang diterima dari lingkungan, misalnya keluarga pada masa kecil."[2]

Pendidikan merupakan usaha manusia untuk menumbuhkan dan mengembangkan potensi-potensi pembawaan baik jasmani maupun rohani sesuai dengan nilai-nilai yang ada dalam masyarakat dan kebudayaan (Ihsan, 2011). Pendidikan bagi kehidupan manusia merupakan kebutuhan mutlak yang harus dipenuhi sepanjang hayat, tanpa pendidikan mustahil manusia dapat hidup berkembang sejalan dengan aspirasi (cita-cita) untuk maju dan sejahtera menurut konsep pandangan hidup mereka (Susiati, et.al, 2020).

Ki Hadjar Dewantara memandang karakter itu sebagai watak atau budi pekerti. Dengan adanya budi pekerti, manusia akan menjadi pribadi yang merdeka sekaligus berkepribadian, dan dapat mengendalikan diri sendiri. Pendidikan dikatakan optimal, jika tabiat luhur lebih menonjol dalam diri anak didik ketimbang tabiat jahat. Manusia berkarakter tersebut sebagai sosok yang beradab, sosok yang menjadi ancangan sejati Pendidikan. Oleh karena itu, keberhasilan Pendidikan yang sejati ialah menghasilkan manusia yang beradab bukan mereka yang cerdas secara kognitif dan psikomotorik tapi miskin karakter atau budi pekerti luhur.[3]

Pendidikan karakter merupakan pendidikan ihwal karakter, atau pendidikan yang mengajarkan hakikat karakter dalam ketiga ranah, yaitu cipta, rasa, dan karsa. Berikut adalah makna pendidikan karakter.

1. Pendidikan karakter merupakan pendidikan yang mendukung perkembangan sosial, emosional, dan etis siswa)." Merujuk pada definisi di atas, pendidikan karakter pada prinsipnya adalah upaya untuk menumbuhkan kepekaan dan tanggung jawab sosial, membangun kecerdasan emosional, dan mewujudkan siswa yang memiliki etika tinggi. Sedari kecil, orangtua kita telah melaksanakan pendidikan karakter (yang waktu itu belum dilabelisasi sebagai penanaman karakter) yang menyangkut pendidikan sosial, emosional, dan etika.

2. Dirjen Dikti menyatakan, "Pendidikan karakter dapat dimaknai sebagai pendidikan nilai, pendidikan budi pekerti, pendidikan moral, pendidikan watak, yang bertujuan mengembangkan kemampuan peserta didik untuk memberikan keputusan baik-buruk, 
memelihara apa yang baik, mewujudkan, dan menebar kebaikan itu dalam kehidupan sehari-hari dengan sepentih hati." [4]

Menurut Suyanto, setidaknya terdapat Sembilan pilar karakter yang berasal dari nilai-nilai luhur universal. Kesembilan karakter tersebut hendaknya menjadi dasar Pendidikan karakter sejak kanak-kanak atau yang biasa disebut para ahli psikologi sebagai usia emas (golden age). Kesembilan pilar tersebut sebagai berikut:

1. Cinta kepada Allah dan segenap isi-Nya

2. Kemandirian dan tanggung jawab

3. Kejujuran/amanah

4. Hormat dan santun

5. Dermawan, suka menolong, dan santun

6. Percaya diri, pekerja keras, dan pantang menyerah

7. Kepemimpinan dan keadilan

8. Baik dan rendah hati

9. Toleransi, cinta damai, dan persatuan[5]

\section{B. Urgensi Pendidikan Karakter}

Kata urgen dimaknai sebagai sebuah kemendesakkan. Mendesak artinya segera untuk diatasi, segera dilaksanakan, dan jika tidak akan ada potensi yang membahayakan. Sesuatu dikatakan mendesak karena ada tanda-tanda yang mengharuskan suatu tindakan dilaksanakan, dapat pula waktunya sangat mepet sehingga harus sesegera mungkin. Mengapa pendidikan karakter mendesak untuk dilaksanakan.

Ada gejala-gejala yang menandakan tergerusnya karakter bangsa ini. Tandatanda merosotnya karakter bangsa ini, senyampang apa yang dinyatakan Thomas Liekona tentang sepuluh tanda zaman yang kini terjadi, yakni sebagai berikut:

1. Meningkatnya kekerasan di kalangan remaja masyarakat. Kekerasan di kalangan remaja dan masyarakat akhir-akhir ini memang meningkat. Tawuran antarpelajar, bahkan antar mahasiswa yang Sejatinya merupakan para calon intelektual terjadi di mana-mana, Kasus tertentu yang dihakimi sendiri menjadi fenomena yang banyak kita temui di masyarakat.

2. Penggunaan bahasa dan kata kata yang tidak baku. Kata dan bahasa yang tidak baku menjadi fenomena di tengah masyarakat. Pengunaan bahasa prokem yang mra historis berai dari komunitas tertentu menjamur di mana-mana. Semisal, "Titi DJ" (hati-hati-hati di jalan) dan sejenisnya bahkan sempat dikamuskan. Belakangan muncul bahasa day yang kehadirannya dipicu oleh pola komunikasi dengan SMS yang memiliki keterbatasan karakter.

3. Pengaruh peer-group (geng) dalam tindak kekerasan menguat. Kemunculan geng (terutama anak sma) di kota-kota muncul dalam kelompok geng-geng motor.

4. Meningkatnya perilaku merusak diri, seperti penggunaan narkoba, alcohol, dan seks bebas.

5. Semakin kaburnya pedoman moral bank dan buruk. Moral kini dalam bayang-bayang sudut pandang relatif. Baik dan buruk bergantung pada siapa dan apa sudut 
pandangnya. Hal ini sejatinya tidak boleh terjadi karena sesungguhnya baik dan buruk itu sifatnya pasti dan diatur dalam berbagai agama.

6. Etos kerja yang menurun. Etos kerja yang dipicu oleh spirit yang lemah, artinya pemahaman sebagai bentuk ibadah tidak dihayati.

7. Semakin rendahnya rasa hormat kepada orang tua dan guru. Rendahnya hormat pada orangtua dan guru disebabkan oleh banyak faktor:

a. gagalnya orangtua sebagai figur bagi anak-anaknya.

b. lingkungan yang tidak kondusif.

c. pemahaman agama yang dangkal.

d. pola asuh anak yang salah.

8. Rendahnya rasa tanggung jawab individu dan kelompok. Perilaku tidak tanggung jawab terjadi di mana-mana, membuang sampah sembarangan, bahkan membunuh bayi hasil hubungan gelap, merokok di sembarang tempat, dan lain-lain. Tanggung jawab rendah karena ketiadaan sanksi yang tegas dari penegak hukum dan sanksi moral dari masyarakat.

9. Budaya kebohongan/ketidakjujuran. Korupsi, kolusi, dan nepotisme berawal dari ketidak jujuran. Bahkan, di dunia pendidikan, ancaman budaya tidak jujur merebak ketika guru-guru dan siswa berkonspirasi dalam Ujian Nasional.

10. Adanya rasa saling curiga dan kebencian antar-sesama. Curiga dan kebencian berawal dari clash of ignorance (benturan karena ketidakpedulian). Kasus konflik antargolongan, saling truth claim dalam berbagai persoalan bersumber pada ketidak pedulian tersebut. Dalam kondisi seperti ini, yang dibutuhkan tidak sekadar bagaimana bertoleransi, tetapi bagaimana membangun komunikasi antarelemen masyarakat.[6]

\section{Pendidikan karakter dalam perspektif Islam}

Pembentukan watak atau karakter tentunya harus dimulai dari pribadi/diri sendiri, dalam keluarga terutama orangtua sebagai pendidiknya. Dalam Islam terdapat tiga nilai utama, yaitu akhlak, adab, dan keteladanan. Akhlak merujuk kepada tugas dan tanggung jawab selain syari' ah dan ajaran Islam secara umum. Sedangkan adab merujuk pada sikap yang dihubungkan dengan tingkah laku yang baik. Dan keteladanan merujuk pada kualitas karakter yang ditampilkan oleh seorang muslim yang baik mengikuti keteladanan Nabi Muhammad SAW. Ketiga nilai inilah yang menjadi pilar Pendidikan karakter dalam Islam.[7]

\section{Karakter Esensial Dalam Islam}

Pendidikan karakter merupakan hal utama dan paling utama yang harus dimiliki setiap individu. Karakter esensial yang dimiliki oleh individu akan membawa implikasi positif bagi terbangunnya karakter Yang lain. Karakter esensial dalam Islam mengacu Pada Sifat Nabi Muhammad Saw. yang meliputi sidik, amanah, fathanah, dan tabligh.

Dari karakter esensial ini, diharapkan terbentuk insan profetik. Insan dengan watak profetik tidak memikirkan dirinya sendiri, tetapi berpikir bagaimana dapat memberikan sebanyak-banyaknya bagi lingkungan (altruistik). Altruistik diartikan sebagai kewajiban yang ditujukan pada kebaikan orang lain. Altruisme pada dasarnya dianjurkan oleh 
semua agama. Dalam lslam, ada ajaran yang menyatakan bahwa sebaik-baiknya manusia adalah yang berguna bagi orang lain.

Sedangkan, ciri-ciri karakter Esensial menurut Syaiful Anam dalam Bukunya Barnawi dan M. Arifin yang berjudul "Pembelajaran Pendidikan Karakter" adalah sebagai berikut:[8]

1. Sadar sebagai makhluk ciptaan Allah. Sadar sebagai makhluk muncul ketika ia mampu memahami keberadaan dirinya, alam sekitar, dan Tuhan Yang Maha Esa. Konsepsi ini dibangun dari nilai-nilai transendensi. Nilai-nilai transedensi merupakan nilai-nilai keilahian. Dari pemahaman akan keberadaan diri yang tidak lepas dari nilai transedensi, sehingga segala sesuatu dijalani dengan niat ibadah.

2. Cinta Allah. Orang yang sadar akan keberadaan Allah meyakini bahwa ia tidak dapat melakukan apa pun tanpa kehendak Allah. Keyakinan ini memunculkan rasa cinta kepada Allah. Orang yang cinta Allah akan menjalankan apa pun perintah dan menjauhi larangan-Nya. Karena sesuatu datangnya dari Allah (dengan usaha yang sungguhsungguh), pencapaian akan segala sesuatu tidak murni karena usaha kita, namun ada kehendak Allah. Atas kesadaran ini, sifat sombong, riya', dan sejenisnya tidak akan ada.

3. Bermoral jujur, saling menghormati, tidak sombong, suka membantu, dan lain-lain merupakan sifat dari manusia yang bermoral.

4. Bijaksana, karakter ini muncul karena keluasan wawasan seseorang Dengan keluasan wawasan, ia akan melihat banyaknya perbedaan yang mampu diambil sebagai" kekuatan. Karakter bijaksana ini dapat terbentuk dari adanya penanaman nilai-nilai kebinekaan.

5. Pembelajar sejati. Untuk dapat memiliki wawasan yang luas, seseorang harus senantiasa belajar. Seorang pembelajar sejati pada dasarnya dimotivasi oleh adanya pemahaman akan luasnya ilmu Tuhan (nilai transendensi). Selain itu, dengan penanaman nilai-nilai kebhinekaan, ia akan semakin bersemangat untuk mengambil kekuatan dari sekian banyak perbedaan. Islam mengajarkan bahwa seorang Muslim hendaknya menjadi manusia pembelajar. Hal ini dapat dicermati dari ajaran yang menyatakan, "Carilah ilmu hingga ke negeri China". Ajaran lain juga menganjurkan bahwa ketika seorang Muslim dalam perjalanan dan menjumpai majelis ilmu, berhentilah dan ikuti majelis tersebut.

6. Mandiri. Karakter. ini muncul dari penanaman nilai-nilai humanisasi dan liberasi. Dengan pemahaman bahWa tiap manusia dan bangsa memiliki potensi dan sama-sama subjek kehidupan, ia tidak akan membenarkan adanya penindasan sesama manusia. Dari pemahaman ini, memunculkan sikap mandiri sebagai bangsa.

\section{Tujuan Pendidikan Karakter dalam Islam}

Pengetahuan keagamaan yang selalu dipupuk di ruang-ruang kelas dan tempattempat ibadah, tidak akan membuat suatu masyarakat menjadi relligius apabila itu semua hanya mengisi ruang kognitif belaka, tanpa penghayatan yang dihujamkan ke hati nurani, tindakan, dan pemiliran pemeluknya.[9]Pendidikan tidak hanya bertitik berat pada kecerdasan intelektual saja melainkan juga pembentukan karakter anak. Pendidikan tidak hanya sekedar proses belajar guna mengejar kecerdasan tetapi juga 
harus mengembangkan potensi lain yang dimiliki peserta didik dan mendapat perhatian dari pendidik agar dapat berkembang secara optimal.

Dari beberapa pengertian di atas maka, karakter tersebut sangat identik dengan akhlak, sehingga karakter dapat diartikan sebagai perwujudan dari nilai-nilai perilaku manusia yang universal serta meliputi seluruh aktivitas manusia, baik hubungan antar manusia dengan tuhan (hablumminallah), hubungan manusia dengan manusia (hablumminannas) serta hubungan manusia dengan lingkungannya. Oleh karena itu, dalam perspektif Islam, karakter atau akhlak mulia merupakan suatu hasil yang dihasilkan dari proses penerapan syariat (Ibadan dan muamalah) yang dilandasi oleh fondasi aqidah yang kokoh dan bersandar pada al-Quran dan as-Sunah (hadis).

Menurut Abd. Hamid sebagaimana dikutip Zubaedi (2012:66) menyatakan bahwa".

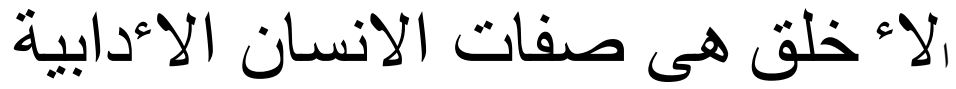

Artinya:"Akhlak ialah segala sifat manusia yang terdidik".

Memahami pernyataan tersebut dapat dimengerti bahwa sifat atau potensi yang dibawa manusia sejak lahir, maksudnya potensi ini sangat tergantung bagaimana cara pembinaan dan pembentukannya. Apabila pengaruhnya positif, maka sama seperti pendidikan karakter, pendidikan akhlak juga outputnya adalah akhlak mulia dan sebaliknya apabila pembinaannya negatif, yang terbentuk adalah akhlak mazmuniah[2].

Maka dari itu al-Ghazali mendefinisikan akhlak sebagai berikut:

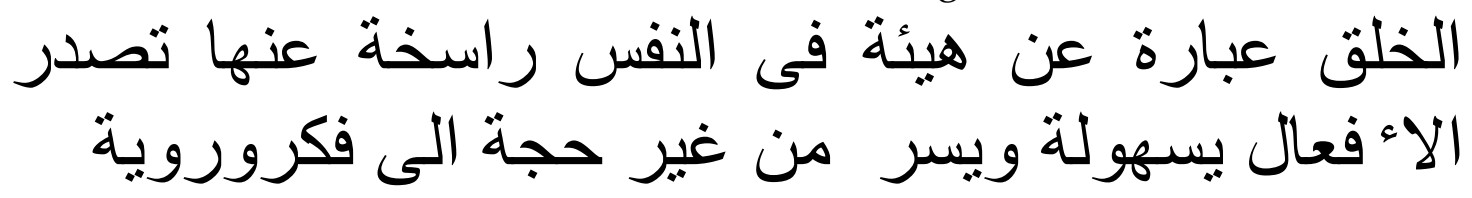

Artinya:"Akhlaq adalah suatu perangai (watak/tabiat) yang menetap dalam jiwa seseorangdan merupakan sumber timbulnya perbuatan-perbuatan tertentu dari dirinya secara mudah dan ringan tanpa dipikirkan atau direncanakan sebelumnya". (Zubaedi.2012: 67)

Jadi, pendidikan karakter menurut pandangan Islam adalah usaha sadar yang dilakukan pendidik kepada peserta didik untuk membentuk kepribadian peserta didik yang mengajarkan dan membentuk moral, etika, dan rasa berbudaya yang baik serta berakhlak mulia yang menumbuhkan kemampuan peserta didik untuk memberikan keputusan baik dan buruk serta mewujudkan kebaikan itu dalam kehidupan sehari-hari dengan cara melakukan pendidikan, pengajaran, bimbingan dan pelatihan yang berpedoman pada al-Quran dan as-Sunah.

Tidak mungkin karakter atau akhlak mulia akan terwujud pada diri seseorang apabila ia tidak memiliki aqidah dan syariah yang benar. Seorang Muslim yang memiliki aqidah atau iman yang benar pasti akan terwujud pada sikap dan perilaku dalam kehidupan sehari-hari yang didasari oleh imannya. Sebagai contoh, orang yang memiliki iman yang baik dan benar kepada Allah SWT ia akan selalu mentaati dan melaksanakan seluruh perintah Allah SWT dan menjauhi seluruh larangan-larangan Nya. Maka dari itu, ia akan selalu berbuat yang baik dan menjauhi hal-hal yang dilarang (buruk).

Tujuan dari pendidikan karakter menurut Islam adalah menjadikan manusia yang berakhlak mulia. Dalam hal ini yang menjadi tolok ukur adalah akhlak Nabi Muhammad 
SAW dan yang menjadi dasar pembentukan karakter adalah al-Quran. Tetapi kita kita harus menyadari tidak ada manusia yang menyamai akhlaknya dengan Nabi Muhammad SAW.Sebagaimana seperti dalam hadis riwayat Muttafaq 'alaih, berikut:

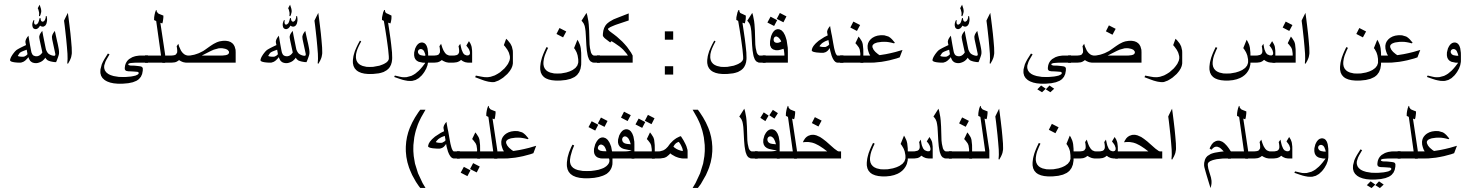

Artinya:"Anas ra. Berkata, "Rasulullah Saw. adalah orang yang paling baik budi pekertinya"'..(Muttafaq 'alaih).

Tujuan pendidikan karakter menurut Islam adalah membentuk pribadi yang berakhlak mulia, karena Akhlak mulia adalah pangkal kebaikan. Orang yang berakhlak mulia akan segera melakukankebaikan dan meninggalkan keburukan.

\section{PEMIKIRAN KRITIS}

Setelah mengetahui tentang konsepsi pendidikan karakter yang telah dijelaskan, maka pandangan Islam terhadap pendidikan karakter menganggap bahwa pendidikan karakter itu sama dengan pendidikan akhlak. Akhlak atau karakter sangat penting, karena akhlak adalah kepribadian yangmempunyai tiga komponen, yaitu tahu (pengetahuan), sikap, dan perilaku. Hal tersebutmenjadi penanda bahwa seseorang itu layak atau tidak layak disebut manusia. Karakteradalah watak, sifat, atau hal-hal yang memang sangat mendasar yang ada pada diriseseorang. Hal-hal yang sangat abstrak yang ada pada diri seseorang. Sering orangmenyebutnya dengan tabiat atau perangai.

Pendidikan karakter pada hakikatnya merupakan pembinaan personal peserta didik secara terprogram dengan tujuan tertentu bagi lembaga pendidikan. Sekolah secara umum ataupun sekolah dalam pengertian luas di lingkungan keluarga dan masyarakat dalam pendidikan karakter menitikberatkan pembinaan ideologi agama, budaya bangsa yang unggul dan jiwa kepemimpinan, yang sekaligus membangun kekuatan dan kualitas peserta didik yang berkarakter unggul.

Pada prinsipnya, tujuan pendidikan harus selaras dengan tujuan yang menjadi landasan dan dasar pendidikan. Karena tujuan pendidikan bersifat universal dan selalu aktual pada segala masa dan zaman. Konsep adanya pendidikan karakter pada dasarnya berusaha mewujudkan peserta didik atau manusia yang berkarakter ( akhlak mulia) sehingga dapat menjadi insan kamil.

Dengan berbagai penjelasan di atas, yang berkaitan dengan pendidikan karakterdalam perspektif Islam, maka dapat dijelaskan bahwa pendidikan karakter dalam Islamsama halnya dengan "akhlak". Sehingga pendidikan karakter dalam pespektif Islamlebih menitikberatkan pada sikap peserta didik, yang hal tersebut pada kehendak positif yang dibiasakan, sehingga dia mampu menimbulkan perbuatan dengan mudah, tanpa pertimbangan pemikiran lebih dahulu dalam kehidupan sehari-hari.

Kedudukan akhlak sangatlah urgen dalam kehidupan manusia, sehingga Allahmengutus Nabi Muhammad SAW. ke muka bumi ini adalah untuk memperbaiki akhlakmanusia. Akhlak adalah corak seseorang atau penentu bahwa orang tersebut 
baikataupun buruk, sehingga dengan inilah akhlak selalu dijadikan penentu paling terdepandalam setiap persoalan, termasuk dalam membangun bangsa Indonesia.

Penerapan pendidikan karakter yang diterapkan di lembaga pendidikan Islam sangatlah komplit, tidak hanya pada kejujuran saja, akan tetapi juga terkait dengan bagaimana mereka manjadi anak yang selalu terbiasa hidup disiplin, hemat, berfikir kritis, berperilaku qanaah, toleran, peduli terhadap lingkungan, tidak sombong, optimis,terbiasa berperilaku ridha, produktif, dan obyektif. 


\section{PENUTUP}

\section{A. Kesimpulan}

Pendidikan karakter merupakan pendidikan ihwal karakter, atau pendidikan yang mengajarkan hakikat karakter dalam ketiga ranah, yaitu cipta, rasa, dan karsa.

Adapun urgensi pendidikan karakter, diantaranya: Meningkatnya kekerasan di kalangan remaja masyarakat, Penggunaan bahasa dan kata kata yang tidak baku, Pengaruh peer-group (geng) dalam tindak kekerasan menguat, Meningkatnya perilaku merusak diri, seperti penggunaan narkoba, alcohol, dan seks bebas, Semakin kaburnya pedoman moral bank dan buruk, Etos kerja yang menurun, Semakin rendahnya rasa hormat kepada orang tua dan guru, gagalnya orangtua sebagai figur bagi anak-anaknya, lingkungan yang tidak kondusif, pemahaman agama yang dangkal, dan lain-lain.

Karakter esensial yang dimiliki oleh individu akan membawa implikasi positif bagi terbangunnya karakter Yang lain. Karakter esensial dalam Islam mengacu Pada Sifat Nabi Muhammad Saw. yang meliputi sidik, amanah, fathanah, dan tabligh. 


\section{DAFTAR PUSTAKA}

Andayani, Dian dan Abdul Majid.Pendidikan Karakter Persepektif lslam. Bandung: Remaja Rosdakarya. 2012.

Adisusilo, Sutarjo. Pembelajaran Nilai Karakter. Jakarta: Rajawali Press. 2013.

Muhaimin, Akhmad. Urgensi Pendidikan Karakter di Indonesia. Yogyakarta: Ar-Ruzz Media. 2013.

Barnawi dan M. Arifin, Strategi Dan Kebijakan Pembelajaran Pendidikan Karakter. Jogjakarta: Ar-Ruzz. 2013.

Syifa,Ainis. Pendidikan Karakter dalam Perspektif Islam. Jurnal Pendidikan Universitas Garut, vol. 08. No. 01. 2014.

Mustari,Mohamad.NIlai Karakter Refleksi Untuk Pendidikan.Raja Grafindo Persada: Jakarta. 2014.

Iye, R., \& Susiati, S. (2018). NILAI EDUKATIF DALAM NOVEL SEBAIT CINTA DI BAWAH LANGIT KAIRO KARYA MAHMUD JAUHARI ALI (Educative Values in Sebait Cinta di Bawah Langit Kairo by Mahmud Jauhari Ali). Sirok Bastra, 6(2), 185191.

Ritzer, G. (2014). Teori Sosiologi Modern. Terjemahan. Jakarta: Kencana Prenadamedia Group.

Susiati, S., Masniati, A., Tuasalamony, K., Hatuwe, R. S. M., Tahir, S. Z. B., Tenriawali, A. Y., \& Marasabessy, R. N. (2020). MEMBANGUN KETAHANAN RELEGIUS ANAK MELALUI ACTIVE PARENTAL INVOLVEMENT. Jurnal Islam Nusantara, 4(1), 111125.

Susiati, \& Taufik. (2019). Nilai Pembentuk Karakter Masyarakat Wakatobi Melalui Kabhanti Wa Leja. Jurnal Totobuang, 7(1), 117-137.

Susiati, S., Iye, R., \& Suherman, L. O. A. (2019). Hot Potatoes Multimedia Applications in Evaluation of Indonesian Learning In SMP Students in Buru District. ELS Journal on Interdisciplinary Studies in Humanities, 2(4), 556-570.

Susiati, S., Masniati, A., \& Iye, R. (2021). Kearifan Lokal Dalam Perilaku Sosial Remaja Di Desa Waimiting Kabupaten Buru. Sang Pencerah: Jurnal Ilmiah Universitas Muhammadiyah Buton, 7(1), 8-23.

Susiati, S. (2020). Nilai Budaya Suku Bajo Sampela Dalam Film The Mirror Never Lies Karya Kamila Andini.

Susiati, S., Tenriawali, A. Y., Nursin, N., Nacikit, J., \& Mukadar, S. (2020). NILAI EDUKASI DALAM NOVEL PARTIKEL KARYA DEWI LESTARI:(The Value of Education in Particle Novels by Dewi Lestari). Uniqbu Journal of Social Sciences, 1(3), 176-183.

Tuasalamony, K., Hatuwe, R. S. M., Susiati, S., Masniati, A., \& Marasabessy, R. N. (2020). PENGEMBANGAN PENDIDIKAN KARAKTER DI SEKOLAH DASAR NEGERI 5 NAMLEA. Pedagogy, 7(2), 81-91.

Hatuwe, Rahma Satya Masna., Tuasalamony, Kurniati., Susiati, Susiati, Masniati, Andi., dan Yusuf, Salma. (2021). MODERNISASI TERHADAP PERUBAHAN SOSIAL 
MASYARAKAT DESA NAMLEA KABUPATEN BURU. Nusantara: Jurnal Ilmu Pengetahuan Sosial, 8(1), 84-96

Wibowo, Agus dan Sigit Purnama.Pendidikan Karakter di Perguruan Tinggi. Yogyakarta: Pustaka Pelajar. 2013. 